Biol. Proced. Online 2004;6(1): 257-262.

doi: $10.1251 /$ bpo96

\title{
Synthesis, Purification and Crystallization of Guanine-rich RNA Oligonucleotides
}

\author{
Baocheng Pan ${ }^{1}, \mathrm{Ke} \mathrm{Shi}^{1}$ and Muttaiya Sundaralingam* \\ 'Departments of Chemistry and Biochemistry, The Ohio State University, 200 Johnston Laboratory, \\ Columbus, $\mathrm{OH} 43210$.
}

*To whom correspondence should be addressed: Muttaiya Sundaralingam, Phone: 614-292-2925; Fax: 614-292-2524; Email: sundaral@chemistry.ohio-state.edu

Submitted: March 10, 2004; Revised: October 22, 2004; Accepted: November 2, 2004; Published: November 22, 2004.

Indexing terms: Isolation and Purification; Crystallization; Oligonucleotides.

\begin{abstract}
Guanine-rich RNA oligonucleotides display many novel structural motifs in recent crystal structures. Here we describe the procedures of the chemical synthesis and the purification of such RNA molecules that are suitable for X-ray crystallographic studies. Modifications of the previous purification methods allow us to obtain better yields in shorter time. We also provide 24 screening conditions that are very effective in crystallization of the guanine-rich RNA oligonucleotides. Optimal crystallization conditions are usually achieved by adjustment of the concentration of the metal ions and $\mathrm{pH}$ of the buffer. Crystals obtained by this method usually diffract to high resolution.
\end{abstract}

\section{INTRODUCTION}

Guanine-rich (G-rich) segments are widely found in RNA molecules $(1,2)$. These segments are crucial in some biological functions such as in mRNA turn over process (3), packaging of HIV RNA (1) and a possible regulatory role in cellular metabolism (4). The mechanism of downstream frameshifting in translational recoding of mRNA arises from guanine tetraplex structure (5). Sequences of consecutive guanines are sometimes interrupted by adenines, as shown in UGGGGGGAGGGAGGGAGGGA of the 3'-untranslated region of chicken elastin mRNA (6), and GGAGG in ShineDalgarno sequence (7). These sequences may participate in biological processes. For instance, the fragile $\mathrm{X}$ mental retardation protein binds specifically to a purine-rich fragment containing both guanine and adenine in its mRNA (8). Similarly, consecutive guanines are sometimes interrupted by pyrimidines in some biological systems, such as GUGG and GCGG in 5S rRNA (9), and IGF quartet in FBS (8). The auxiliary downstream element in SV40 L pre-mRNA r(GGGGGAGGUGUGGG) (10) is an example of the sequences of consecutive guanines embedded with pyrimidines, which is bound by hnRNA H/H' protein and their interaction may stimulate the polyadenylation of SV40 L pre-mRNA (11).

G-rich oligonucleotides display quite versatile structural characteristics (12) and recent crystallographic studies have added new features to the structural repertoire (13-18). Four consecutive guanines can form guanine-tetraplex in both solution $(19,20)$ and crystalline state $(13,21,22)$. When one guanine is replaced with an adenine or a uridine, an eight-stranded helical fragment (17) and a bulged tetraplex (18) have been observed. All these observations indicate that $G$-rich regions possess greater potentials in forming three-dimensional conformations than we have expected. These structural evidences imply that G-rich

(C) 2004 by the author(s). This paper is Open Access and is published in Biological Procedures Online under license from the author(s). Copying, printing, redistribution and storage permitted. Journal C 1997-2004 Biological Procedures Online. 
segments may be involved in some biological processes that we have not found yet. Thus, the research of the RNA molecules with G-rich segments may unveil the biological roles of these molecules and enrich our knowledge about base pairing schemes such as base tetrads and base octads and formation of multistranded helices.

Chemical synthesis and purification of RNA oligonucleotides have experienced great improvement since the 1990s. The general principles and methods of synthesis and crystallization of RNA molecules have been summarized and described previously (23-29). G-rich oligonucleotides have their own characteristic features and their conformations strongly depend on their interaction with metal ions (30). Our experience shows that oligonucleotides that contain more than four consecutive guanines may suffer some difficulty in purification. Also the present screening conditions of crystallization for oligonucleotides usually emphasize the effect of $\mathrm{Mg}^{2+}$ ion (26, 27). However, $\mathrm{Mg}^{2+}$ ion does not have strong stabilization effect on the formation of G-tetraplexes (30). Here we provide an effective method in synthesis, purification and crystallization of G-rich segments of RNA molecules, which is essential in study of these RNA molecules by X-ray crystallography.

\section{MATERIALS AND METHODS}

\section{Chemical synthesis and deprotection of oligonucleotides}

Phosphoramidites (including the bromo-derivatives) and all other reagents for the synthesis of G-rich RNA oligonucloetides were purchased from Glen Research Corporation. All other chemicals were purchased from Aldrich Chemical Company without further purification. Oligonucleotides were synthesized on Applied Biosystem Synthesizer 391 on $1 \mu \mathrm{mol}$ scale, using the standard phosphoramidite chemistry (Protocol I). The synthesized oligonucleotides were then deprotected (Protocol II). The sample was first dried by argon flush in the synthesizer and then incubated in a solution of $30 \%(\mathrm{v} / \mathrm{v})$ ethanol in ammonium hydroxide. During the incubation, the RNA oligonucleotides were cleaved off the solid phase and the cyanoethyl-protecting group of phosphate was also removed. The mixture of ammonium hydroxide and ethanol was used here instead of only ammonium hydroxide for DNA oligonucleotides because of the hydrophobicity of the bulky silyl group in RNA. The solution was then lyophilized to dryness. To deprotect the 2'-hydroxyl group, we added $1.0 \mathrm{ml}$ to $1.5 \mathrm{ml}$ solution of $3: 1(\mathrm{v} / \mathrm{v})$ triethylamine trihydrofluoride: $\mathrm{N}, \mathrm{N}$-dimethylformamide to the sample and let it stay at $55^{\circ} \mathrm{C}$ for 2 to 3 hours. We used 1-butanol to precipitate the RNA because it has stronger precipitating effect than ethanol. The solution was kept in $-20^{\circ} \mathrm{C}$ for 6 hours or overnight and then was centrifuged. The supernatant was decanted and the pellet was saved. In order to get rid of the residual 1-butanol which may clog the needle in loading the sample in FPLC, we used $5 \mathrm{ml}$ ethanol to wash the pellet, which was then lyophilized to dryness.

\section{lon-exchange FPLC}

Chromatographic separation was carried out on a Pharmacia FPLC system employing an ion exchange column SourceQ (5 $\mathrm{mm}$ internal dimension, $1.00 \mathrm{ml}$ gel bed) (Protocol III). Samples were dissolved in $400 \mu \mathrm{l}$ distilled water and loaded onto the column at the flow rate of $1 \mathrm{ml} / \mathrm{min}$. After washing with $10 \mathrm{ml}$ loading buffer (0.05 M ammonium bicarbonate, 20\% acetonitrile), samples were eluted at a gradient from 5\% to $100 \%$ eluting buffer (1.5 M ammonium bicarbonate, $20 \%$ acetonitrile) in 60 minutes and at the flow rate of $2.5 \mathrm{ml} / \mathrm{min}$. The process was monitored with the absorbance at $260 \mathrm{~nm}$. The last big peak coming out of the column usually corresponds to our target molecules. The collected fraction of the absorbance peak was lyophilized to dryness several times with adding distilled water in between until fluffy material has obtained.

\section{Preparation for crystallization trials}

The oligonucleotides in fluffy form were weighed to the nearest $0.01 \mathrm{mg}$ and $2 \mathrm{mM}$ single-stranded concentration was made with distilled water. The G-rich oligonucleotides were annealed at $90^{\circ} \mathrm{C}$ and crystallization was carried out at room temperature. The samples were stored at $-20^{\circ} \mathrm{C}$ before and after crystallization trials.

\section{Crystallization methods}

Hanging drop vapor diffusion method was employed in all crystallization trials. Stock solutions of 24 screening conditions were pre-prepared (Table 1). In setting up crystallization trays, 2 $\mu \mathrm{l}$ of stock solution and $2 \mu \mathrm{l}$ of RNA samples were added on siliconized glass cover slips. In the cases of optimizing crystallization conditions, components were added without mixing in the following order: buffer, precipitants, polyvalent cations, divalent cations, monovalent cations, and RNA oligonucleotides. Crystals obtained in this method gave highresolution data.

\section{Data collection}

Multi-wavelength anomalous diffraction (MAD) data sets were collected with synchrotron facilities in the Advanced Photon Sources (APS) in the Argonne National Lab. The structures were solved by MAD phasing method and refined with CNS program package (31). Because of the versatility of G-rich sequences, it is difficult to predict the conformations of the $G$-rich segments just from their sequences, as shown in our structures of (BrdU)r(GAGGU) (16) and $r(U)(B r d G) r(A G G U) ~(17)$ and $\mathrm{r}(\mathrm{U})(\mathrm{BrdG}) \mathrm{r}(\mathrm{UGGU})$ (18). It is recommended to include the bromo-derivatives in the synthesis of $\mathrm{G}$-rich oligonucleotides and collect MAD data sets in X-ray diffraction data collection. 
Table 1: Crystallization screening conditions*

\begin{tabular}{|c|c|c|}
\hline Condition & Salt & Polyamine \\
\hline 1 & $100 \mathrm{mM} \mathrm{KCl}$ & $2 \mathrm{mM}$ Cobalt hexammine \\
\hline 2 & $100 \mathrm{mM} \mathrm{NaCl}$ & $2 \mathrm{mM}$ Cobalt hexammine \\
\hline 3 & $80 \mathrm{mM} \mathrm{BaCl}_{2}$ & $2 \mathrm{mM}$ Cobalt hexammine \\
\hline 4 & $80 \mathrm{mM} \mathrm{SrCl}_{2}$ & $2 \mathrm{mM}$ Cobalt hexammine \\
\hline 5 & $80 \mathrm{mM} \mathrm{CaCl}_{2}$ & $2 \mathrm{mM}$ Cobalt hexammine \\
\hline 6 & $80 \mathrm{mM} \mathrm{MgCl} 2$ & $2 \mathrm{mM}$ Cobalt hexammine \\
\hline 7 & $\begin{array}{l}100 \mathrm{mM} \mathrm{KCl}+50 \mathrm{mM} \\
\mathrm{NaCl}\end{array}$ & $2 \mathrm{mM}$ Cobalt hexammine \\
\hline 8 & $\begin{array}{l}50 \mathrm{mM} \mathrm{KCl}+100 \mathrm{mM} \\
\mathrm{NaCl}\end{array}$ & $2 \mathrm{mM}$ Cobalt hexammine \\
\hline 9 & $100 \mathrm{mM} \mathrm{KCl}$ & $2 \mathrm{mM}$ Spermine tetra- $\mathrm{HCl}$ \\
\hline 10 & $100 \mathrm{mM} \mathrm{NaCl}$ & $2 \mathrm{mM}$ Spermine tetra- $\mathrm{HCl}$ \\
\hline 11 & $80 \mathrm{mM} \mathrm{BaCl}_{2}$ & $2 \mathrm{mM}$ Spermine tetra- $\mathrm{HCl}$ \\
\hline 12 & $80 \mathrm{mM} \mathrm{SrCl}_{2}$ & $2 \mathrm{mM}$ Spermine tetra- $\mathrm{HCl}$ \\
\hline 13 & $80 \mathrm{mM} \mathrm{CaCl}_{2}$ & $2 \mathrm{mM}$ Spermine tetra- $\mathrm{HCl}$ \\
\hline 14 & $80 \mathrm{mM} \mathrm{MgCl}_{2}$ & $2 \mathrm{mM}$ Spermine tetra- $\mathrm{HCl}$ \\
\hline 15 & $\begin{array}{l}100 \mathrm{mM} \mathrm{KCl}+50 \mathrm{mM} \\
\mathrm{NaCl}\end{array}$ & $2 \mathrm{mM}$ Spermine tetra- $\mathrm{HCl}$ \\
\hline 16 & $\begin{array}{l}50 \mathrm{mM} \mathrm{KCl}+100 \mathrm{mM} \\
\mathrm{NaCl}\end{array}$ & $2 \mathrm{mM}$ Spermine tetra- $\mathrm{HCl}$ \\
\hline 17 & $\begin{array}{l}80 \mathrm{mM} \mathrm{KCl}+20 \mathrm{mM} \\
\mathrm{BaCl}_{2}\end{array}$ & $2 \mathrm{mM}$ Spermine tetra- $\mathrm{HCl}$ \\
\hline 18 & $\begin{array}{l}80 \mathrm{mM} \mathrm{KCl}+20 \mathrm{mM} \\
\mathrm{SrCl}_{2}\end{array}$ & $2 \mathrm{mM}$ Spermine tetra- $\mathrm{HCl}$ \\
\hline 19 & $\begin{array}{l}80 \mathrm{mM} \mathrm{KCl}+20 \mathrm{mM} \\
\mathrm{CaCl}_{2}\end{array}$ & $2 \mathrm{mM}$ Spermine tetra- $\mathrm{HCl}$ \\
\hline 20 & $\begin{array}{l}80 \mathrm{mM} \mathrm{KCl}_{\mathrm{MgCl}_{2}}+20 \mathrm{mM} \\
\end{array}$ & $2 \mathrm{mM}$ Spermine tetra- $\mathrm{HCl}$ \\
\hline 21 & $\begin{array}{l}80 \mathrm{mM} \mathrm{NaCl}^{\mathrm{BaCl}}+20 \mathrm{mM} \\
\mathrm{Bu}_{2}\end{array}$ & $2 \mathrm{mM}$ Spermine tetra- $\mathrm{HCl}$ \\
\hline 22 & $\begin{array}{l}80 \mathrm{mM} \mathrm{NaCl}+20 \mathrm{mM} \\
\mathrm{SrCl}_{2}\end{array}$ & $2 \mathrm{mM}$ Spermine tetra- $\mathrm{HCl}$ \\
\hline 23 & $\begin{array}{l}80 \mathrm{mM} \mathrm{NaCl}+20 \mathrm{mM} \\
\mathrm{CaCl}_{2}\end{array}$ & $2 \mathrm{mM}$ Spermine tetra- $\mathrm{HCl}$ \\
\hline 24 & $\begin{array}{l}80 \mathrm{mM} \mathrm{NaCl}+20 \mathrm{mM} \\
\mathrm{MgCl}_{2}\end{array}$ & $2 \mathrm{mM}$ Spermine tetra- $\mathrm{HCl}$ \\
\hline
\end{tabular}

*Buffer is $40 \mathrm{mM}$ sodium cacodylate ( $\mathrm{pH}$ 6.0); precipitant in the droplet is $5 \%(\mathrm{v} / \mathrm{v}) 2$-methyl-2,4-pentanediol (MPD); reservoir is 30\% MPD.

\section{RESULTS AND DISCUSSION}

\section{Purification}

For G-rich RNA oligonucleotides, ethanol precipitation alone cannot separate the target molecules from the deprotecting agents and other contaminating species. Chromatography must be employed in the purification. Our experience showed that the ion-exchange fast-performance liquid chromatography (FPLC) was preferred over the reverse-phase high-pressure liquid chromatography (HPLC) because of the higher loading capacity of the FPLC column and circumvention of trityl-on chromatography. The results indicated that a single ion-exchange FPLC run was usually sufficient to obtain the purity suitable for $\mathrm{X}$-ray crystallographic study. In the cases of oligonucleotides with more than four consecutive guanines, overlapped peaks in the absorbance profile may appear. This situation means that stronger denaturing conditions are required for the purification in FPLC. An analytical run with higher concentration of acetonitrile or with heated columns (32) may be needed to figure out the appropriate method that should be used for the oligonucleotides. The method of increasing the concentration of acetonitrile is easy but has some limitation. Increase of acetonitrile will decrease the maximum concentration of eluting salts that we can obtain in the eluting buffer. If the target molecules cannot be eluted at $100 \%$ of eluting buffer, we have to change for some other eluting salts (such as from ammonium bicarbonate to lithium chloride) or the heated column may be used.

Ammonium bicarbonate has the advantage over lithium chloride as an eluting salt in that ammonium bicarbonate can vaporize during lyophilization. Ethanol precipitation is not required in order to get rid of the eluting salt. Thus, we avoid loss of sample in ethanol precipitation and save the time waiting for the precipitation. However, lithium chloride has greater solubility than ammonium bicarbonate and thus it is much easier to be dissolved and can have high concentration in solutions containing acetonitrile. Lithium chloride may be a useful eluting salt at high concentration of acetonitrile.

\section{Crystallization}

\section{Buffers and $p H$}

The most commonly employed buffer in crystallization of oligonucleotides is cacodylate. Oligonucleotides are usually not sensitive to $\mathrm{pH}$ of crystallization solutions because the $\mathrm{pKa}$ values of all groups are not near neutral $\mathrm{pH}$ (33). Therefore we did not screen $\mathrm{pH}$ for the first trial of crystallization. However, fine adjustment of the $\mathrm{pH}$ was sometimes useful in obtaining crystals with high quality.

\section{Metal lons}

G-rich segments have strong tendency to form tetraplex structures. Experimental data showed that metal ions are critical for the formation of the tetraplexes which selectively chelate metal ions with suitable ionic radii (30). Previous solution studies showed that tetraplexes can not form without proper monovalent cations (34) and that tetraplexes may adopt different conformations when they interact with $\mathrm{Na}^{+}$and $\mathrm{K}^{+}$ions (35-37). Crystal structures showed that $\mathrm{Na}^{+}$and $\mathrm{K}^{+}$ions locate between every G-tetrad plane along the central axis of DNA tetraplexes $(14,15,21,22)$. On the other hand, divalent cation $\mathrm{Sr}^{2+}$ ions locate between every other G-tetrad plane in an RNA tetraplex (13), and both $\mathrm{Na}^{+}$and $\mathrm{Ba}^{2+}$ ions can co-exist in the central axis of the tetraplex (16). These results show the various coordination of metal ions and the selectivity of metal ions in tetraplexes.

The crystallization conditions presented in this study emphasize the important involvement of metal ions in G-rich oligonucleotides. In the 24 conditions, the important metal ions in tetraplex formation (33) have been screened, including two monovalent metal ions, $\mathrm{Na}^{+}$and $\mathrm{K}^{+}$and four divalent metal ions, $\mathrm{Ba}^{2+}, \mathrm{Sr}^{2+}, \mathrm{Ca}^{2+}$ and $\mathrm{Mg}^{2+}$ (Table 1). Different combinations of 
monovalent cations and divalent cations have also been tested. Once we identified the metal ion(s), different concentrations of the metal ion(s) will be optimized. Our results showed that these conditions are very effective in identifying the metal ions in crystallization of G-rich RNA oligonucleotides and in obtaining crystals that diffract to high resolutions.

\section{ACKNOWLEDGMENTS}

This work was supported by the NIH grant GM-17378 and an Ohio Regents Eminent Scholar Endowment to MS.

\section{REFERENCES}

1. Sundquist WI, Heaphy S. Evidence for interstrand quadruplex formation in the dimerization of human immunodeficiency virus 1 genomic RNA. Proc Natl Acad Sci USA 1993; 90:3393-3397.

2. Christiansen J, Kofod M, Nielsen FC. A guanosine quadruplex and two stable hairpins flank a major cleavage site in insulin-like growth factor II mRNA. Nucl Acids Res 1994; 22:5709-5716.

3. Bashkirov VI, Scherthan H, Solinger JA, Buerstedde WD. A mouse cytoplasmic exoribonuclease (mXRN1p) with preference for G4 tetraplex substrates. J Cell Biol 1997; 136:761-773.

4. Shafer RH, Smirnov I. Biological aspects of DNA/RNA quadruplexes. Biopolymers 2001; 56:209-227.

5. Horsburgh BC, Kollmus H, Hauser H, Coen DM. Translational recoding induced by G-rich mRNA sequences that form unusual structure. Cell 1996; 86:949-959.

6. Hew Y, Lau C, Grzelczak Z, Keeley FWJ. Identification of a GA-rich sequence as a protein-binding site in the 3'untranslated region of chicken elastin mRNA with a potential role in the developmental regulation of elastin mRNA stability. J Biol Chem 2000; 275:24857-24864.

7. Bonham-Smith PC, Bourque DP. Translation of chloroplastencoded mRNA: potential initiation and termination signals. Nucl Acids Res 1989; 17:2057-2080.

8. Schaeffer C, Bardoni B, Mandel JL, Ehresmann B, Ehresmann C, Moine $\mathrm{H}$. The fragile X mental retardation protein binds specifically to its mRNA via a purine quartet motif. EMBO J 2001; 20:4803-4813.

9. Szymanski M, Barciszewska MZ, Erdmann VA, Barciszewski J. 5S ribosomal RNA database. Nucl Acids Res 2002; 30:176-187.

10. Bagga PS, Fordm LP, Chen F, Wilusz J. The G-rich auxiliary downstream element has distinct sequence and position requirements and mediates efficient 3 ' end pre-mRNA processing through a trans-acting factor. Nucl Acids Res 1995; 23:1625-1631.

11. Bagga PS, Arhin GK, Wilusz J. DSEF-1 is a member of the hnRNP $\mathrm{H}$ family of RNA-binding proteins and stimulates pre-mRNA cleavage and polyadenylation in vitro. Nucl Acids Res 1998; 26:5343-5350.

12. Patel DJ, Bouaziz S, Kettani A, Wang Y. Structures of guanine-rich and cytosine-rich quadruplexes formed in vitro by telomeric, centromeric, and triplet repeat disease DNA sequences. In Oxford Handbook of Nucleic Acid Structure, S. Neidle, ed. (Oxford University Press), 1999. p. 389-453.

13. Deng JP, Xiong Y, Sundaralingam M. X-ray analysis of an RNA tetraplex (UGGGGU) 4 with divalent $\mathrm{Sr}^{2+}$ ions at subatomic resolution (0.61 A). Proc Natl Acad Sci USA 2001; 98:13665-13670.

14. Parkinson GN, Lee MPH, Neidle S. Crystal structure of parallel quadruplexes from human telomeric DNA. Nature 2002; 417:876-880.

15. Haider S, Parkinson GN, Neidle S. Crystal structure of the potassion form of an oxytricha nova G-quadruplex. $\mathrm{M} \mathrm{Mol}$ Biol 2002; 320:189-200.

16. Pan B, Xiong Y, Shi K, Deng J, Sundaralingam M. Crystal structure of an RNA purine-rich tetraplex containing adenine-tetrads: implications for specific binding in RNA tetraplex. Structure 2003; 11:815-823.

17. Pan B, Xiong Y, Shi K, Sundaralingam M. An eight-stranded helical fragment in RNA crystal structure: implications for tetraplex interaction. Structure 2003; 11:825-831.

18. Pan B, Xiong Y, Shi K, Sundaralingam M. Crystal structure of a bulged RNA tetraplex at $1.1 \AA$ resolution: implications for a novel binding site in RNA tetraplex. Structure 2003; 11:1423-1430.

19. Kim J, Cheong C, Moore PB. Tetramerization of an RNA oligonucleotide containing a GGGG sequence. Nature 1991; 351:331-332.

20. Cheong C, Moore PB. Solution structure of an unusually stable RNA tetraplex containing $\mathrm{G}$ and $\mathrm{U}$-quartet structures. Biochemistry 1992; 36:8406-8414.

21. Laughlan G, Murchie AIH, Norman DG, Moore $\mathrm{MH}$, Moody PCE, Lilley DMJ, Luisi B. The high-resolution crystal structure of a parallel-stranded guanine tetraplex. Science 1994; 265:520-524.

22. Phillips K, Dauter Z, Murchie AIH, Lilley DMJ, Luisi B. The crystal structure of a parallel-stranded guanine tetraplex at $0.95 \AA$ resolution. $J$ Mol Biol 1997; 273:171-182.

23. Usman N, Egli M, Rich A. Large scale chemical synthesis, purification and crystallization of RNA-DNA chimeras. Nucl Acids Res 1992; 20:6695-6699.

24. Doudna JA, Grosshans C, Gooding A, Kundrot CE. Crystallization of ribozymes and small RNA motifs by a sparse matrix approach. Proc Natl Acad Sci USA 1993; 90:7829-7833.

25. Price SR, Ito N, Oubridge C, Avis JM, Nagai K. Crystallization of RNA-protein complexes. I. Methods for the large-scale preparation of RNA suitable for crystallographic studies. J Mol Biol 1995; 249:398-408.

26. Wahl MC, Ramakrishnan B, Ban C, Chen X, Sundaralingam M. RNA - Synthesis, purification and crystallization. Acta Crystallog D 1996; 52:668-675.

27. Berger I, Kang C, Sinha N, Wolters M, Rich A. A highly efficient 24-condition matrix fo the crystallization of nucleic acid fragments. Acta Crystallog D 1996; 52:465-468.

28. Holbrook SR, Kim SH. RNA crystallography. Biopolymers 1997; 44:3-21.

29. Holbrook SR, Holbrook EL, Walukiewicz HE. Crystallization of RNA. Cell Mol Life Sci 2001; 58:234-243. 
30. Guschlbauer W, Chantot JF, Thiele D. Four-stranded nucleic acid structure 25 years later: From guanosine gels to telomer DNA. J Biomol Struct Dyn 1990; 8:491-511.

31. Brünger AT, Adams PD, Clore GM, DeLano WL, Gros P, Grosse-Kunstleve RW, Jiang JS, Kuszewski J, Nilges M, Pannu NS et al. Crystallography \& NMR System: A New Software Suite for Macromolecular Structure Determination. Acta Crystallog D 1998; 54:905-921.

32. Murray JB, Collier AK, Arnold JR. A general purification procedure for chemically synthesized oligoribonucleotides. Anal Biochem 1994; 218:177-184.

33. Ducruix A, Gieg R eds. Crystallization of Nucleic Acids and Proteins - A Practical Approach. Oxford: IRL Press. 1992.

34. Williamson JR, Raghuraman MK, Cech TR. Monovalent cation-induced structure of telomeric DNA: the G-quartet model. Cell 1989; 59:871-880.

35. Balagurumoorthy P, Brahmachari K. Structure and stability of human telomeric sequence. J Biol Chem 1994; 269:2185821869.

36. Kettani A, Bouaziz S, Gorin A, Zhao J, Jones RA, Patel DJ. Solution structure of a $\mathrm{Na}$ cation stabilized DNA quadruplex containing G-G-G-G and G-C-G-C tetrads formed by G-GG-C repeats observed in adeno-associated viral DNA. J Mol Biol 1998; 282:619-636.

37. Bouaziz S, Kettani A, Patel DJ. A K cation-induced conformational switch within a loop panning segment of a DNA quadruplex containing G-G-G-C repeats. J Mol Biol 1998; 282:637-652. 


\section{PROTOCOLS}

\section{Protocol I: Synthesis of RNA Oligonucleotides in Applied Biosystem Synthesizer 391}

1. Dissolve powder phosphoramidites in bottle with anhydrous acetonitrile. The amount of acetonitrile added is listed in the menu of Applied Biosystem Synthesizer 391.

2. Attach the bottles to ports of the synthesizer according to the letters posted on the synthesizer (A for adenine, $G$ for guanine, $C$ for cytosine, $\mathrm{T}$ for thymine in DNA or uridine in RNA, and $\mathrm{X}$ for other modified phosphoramidites). The bromo-derivative phosphoramidite should be attached to the $\mathrm{X}$-port and corresponds to $\mathrm{X}$ in the sequence.

3. In the Main Menu, select DNA Editor and in the next screen, select Edit and enter the sequence starting with 5'-terminal residue and ending with the 3'-terminal residue with CPG.

4. Return to Main Menu, and select Start Synthesis.

5. Select Trityl OFF for purification by FPLC chromatography with SourceQ column.

6. Monitor the synthesis by observation of the orange color of the eluent. Deep orange color of the eluent for the last residue indicates good synthesis of the whole oligonucleotide.

\section{Protocol II: Deprotection of RNA Oligonucleotides}

1. When the synthesis is complete, use argon flush to dry the product (about 5 minutes). Take off the column from the synthesizer. Unscrew the column and put the powder in a vial of 2 dram. Pour about $4 \mathrm{ml}$ mixture of 30\% EtOH in ammonium hydroxide. (Ammonium hydroxide should not be opened for more than one month and should be stored in freezer).

2. The solution stays at room temperature for 24 hours if the oligonucleotides contain bromo-derivated phosphoramidites and away from light. Otherwise the solution is incubated at $55^{\circ} \mathrm{C}$ overnight.

3. Put the vial in a freezer and let the solution stay inside to be cold enough (about 2 hours) before it is lyophilized to dryness. CAUTION: The solution may spill out at the beginning of lyophilization if it is not cold enough.

4. The sample is stored in freezer if we do not purify the oligonucleotides immediately.

5. Add $1.0 \mathrm{ml}$ to $1.5 \mathrm{ml}$ of mixture $(3: 1)$ of triethylamine-trihydrofluride: $\mathrm{N}$, N-dimethylformamide and incubate at $55^{\circ} \mathrm{C}$ for 2 to 3 hours.

6. Transfer the solution to $50 \mathrm{ml}$ falcon tube. Add $200 \mathrm{ul} \mathrm{H}_{2} \mathrm{O}$ and $20 \mathrm{ml}$ 1-butanol. Leave in the freezer for 6 hours or overnight.

7. Centrifuge for $15 \mathrm{~min}$ (pellet is not solid) and decant the supernatant.

8. Add $5 \mathrm{ml} \mathrm{EtOH}$, vortex for a while and put in freezer and stay for several hours to allow precipitate to form.

9. Centrifuge and decant the supernatant (need to wash away any remaining 1-butanol).

10. Pour $0.4 \mathrm{ml}$ distilled water to dissolve the sample and vortex. If not dissolved well, add $10 \mu \mathrm{l}$ to $20 \mu \mathrm{l}$ of $2 \mathrm{M}$ TEAA (triethylamine acetate).

11. Centrifuge the sample and save the supernatant for FPLC.

\section{Protocol III: Purification of RNA Oligonucleotides with SourceQ FPLC}

1. Wash the SourceQ column with eluting buffer (1.5 M ammonium bicarbonate, $20 \%$ (v/v) acetonitrile) until no absorbance is observed.

2. Wash the SourceQ column with loading buffer (0.05 M ammonium bicarbonate, 20\% (v/v) acetonitrile) for 10 to 20 minutes (about 5 column volume).

3. Load the sample with loading buffer at flow rate of $1 \mathrm{ml} / \mathrm{min}$.

4. Wash with loading buffer for 10 minutes after injection of the sample.

5. Elute the oligonucleotide at a gradient from 5\% to $100 \%$ eluting buffer in 60 minutes.

6. Collect the fractions corresponding to the absorption peak at $260 \mathrm{~nm}$.

7. Lyophilize the collected fractions to dryness.

8. Add $500 \mu \mathrm{l} \mathrm{H}_{2} \mathrm{O}$ and evaporate to dryness. Repeat this process until fluffy materials is obtained.

9. Weigh the product and add distilled water to make $2 \mathrm{mM}$ (single-stranded) RNA stock solution.

10. Anneal the sample at $90^{\circ} \mathrm{C}$ and let it cool down slowly to room temperature by itself.

11. Store in a freezer of $-20^{\circ} \mathrm{C}$. 